\title{
The year in review
}

The present issuc is oux foumb, completing our first year's volume, and I look back

1 over the year with a mixture ol satisfaction and gratitude. Gratitude to the authors who entrusted their work to us. and satisfaction with ils high quality. I am gratelul also to the reviewers, listed on page 270, who promply provicked their opinions and recommendations. The bare boncs of the year are given by a few numbers: 44 submissions. with 30 accepted, cight rejected and six still in review: and 60 revicwers, with an average of

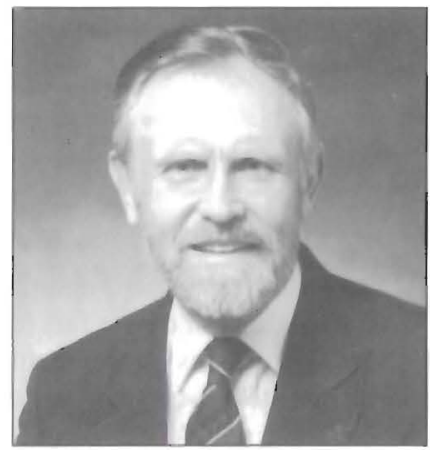
only 28 days in review, with the slowest being two months. The quality of the final papers is very dependent on revicewers, and I halve found it remarkable that their suggestions have been uniformly followed by authors. to the clear benefit of the final manuscript. Also it is at pleasure to acknowledge the outstanding support of everyone at Pulsus Group who, with an understated professionalism, have made the profuction run so smoothly. Their Canadian journals are advancing the reputation of our national clinical research endeavours on several firmts, and they deserve our thanks.

Of course we still have a long way to go and wo swallows do not a summer make. We would be overjoyed to receive more experimental papers, more calse reports, some pipers from surgical colleagues, some publishable correspondence and suggestions to improve our coverage of differemt lopics. Even feedback regarding the papers that readers have found the most enjoyable, informative or practically uscful is ensured of a personal reply from 'The Editor-in-Chief.

On another nolc, I had reason recently to reflect on the pleasures of a classical education, after taking an unwarranted editorial liberty with Marsh Tenney's paper, included in the present issue (pages 241-247). The paper originated some years ago as an elegant introduction to the annual report of the Parker B Francis Foundation, which for many years has provided impressive support for respiratory research and training. Never published elscwhere. it seemed just right for the Journal, and Marsh generously agreed to its inclusion wilh slight changes. As I reviewed the paper I noticed the reterence to Leonardo of Pisa, who was known ats Fibonacei, "a contraction of liglio bonikei, or son of the ox". Priding myself on knowing a little Italian I checked 'bonatcial in the English-Ltalian equivatent whe Shorter Oxford Dictionary and found it meant "strong, docile' also 'calm (of' sea)', but no mention of ox. At this point I should have heeded a tiny voice telling me that the Nathan Smith Professor of Physiology at Dartmouth and the author of those elegant 'Notes' in the News in Physiological Sciences (NIPS) would not have made the reference without sound reason. Instead I removed the passage and told Marsh that I had. Almost by return camc his lefter kelling me ol his chuckle (I think I heard it all the way from Dartmouth) at my action. Then:

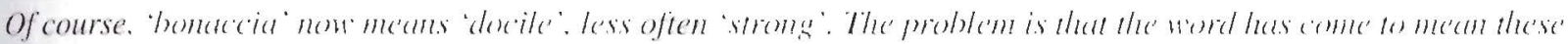

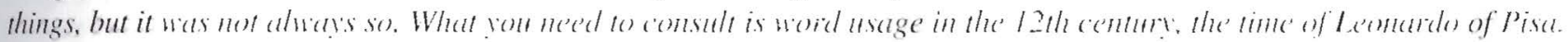

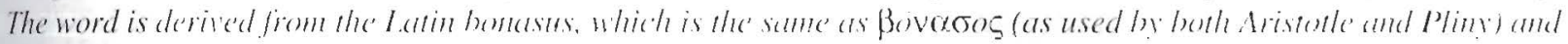

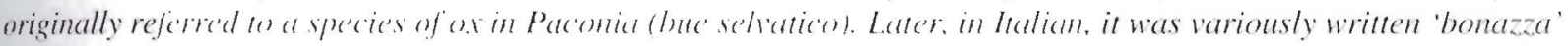

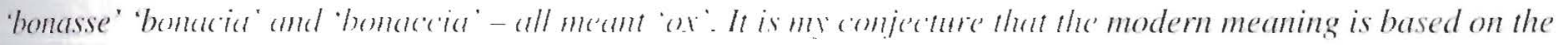

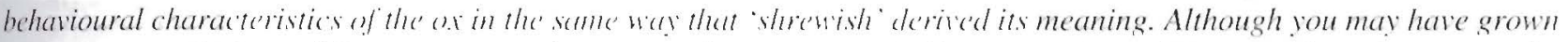

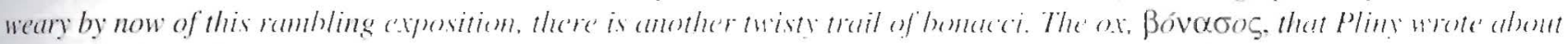

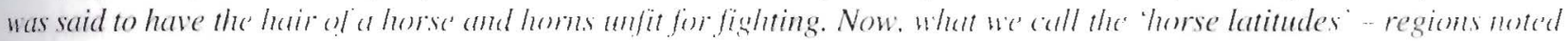
for their calms - are knum in lualian as 'bonacce subropricale'. Language is a strange beast.

I lake some comlont from a guite prolonged and heated discussion on the point between colleagues in the Italian Department at McMaster (niversily. and a mystified response from two professors in Pisa, so that even with their help I have lo concede a notable victory to Marsh. who is clearly capathle of gamesmanship of the highest order.

I am looking lorwart to more correspondence to improve my rudinentary education in the classics. hut in the future will try to keep to the advice of Leopardi (1834): "The most certatin waly to hide from others the limiss ol our hunwledge is not to go beyond them". 


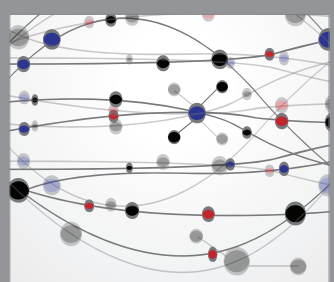

The Scientific World Journal
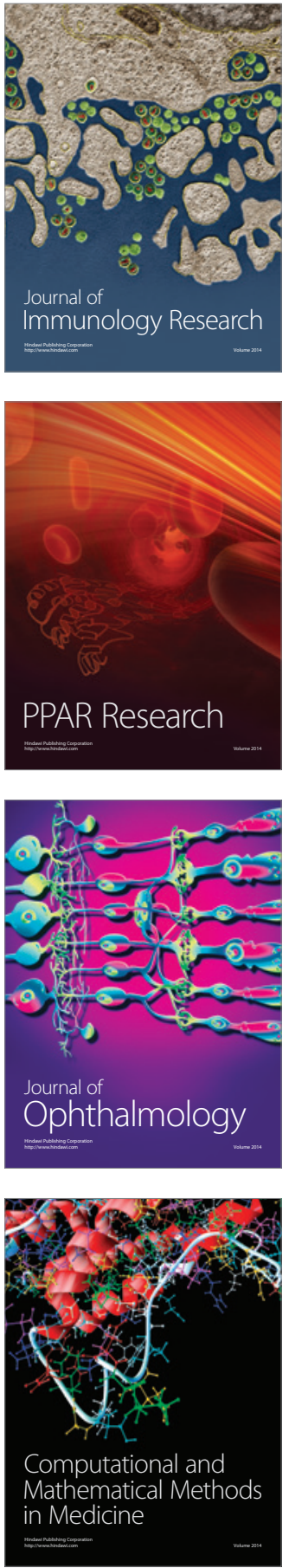

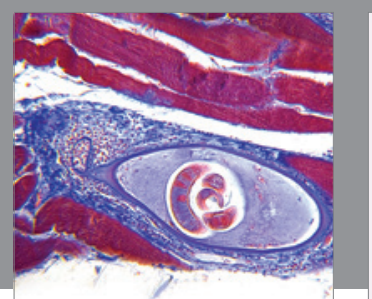

Gastroenterology Research and Practice

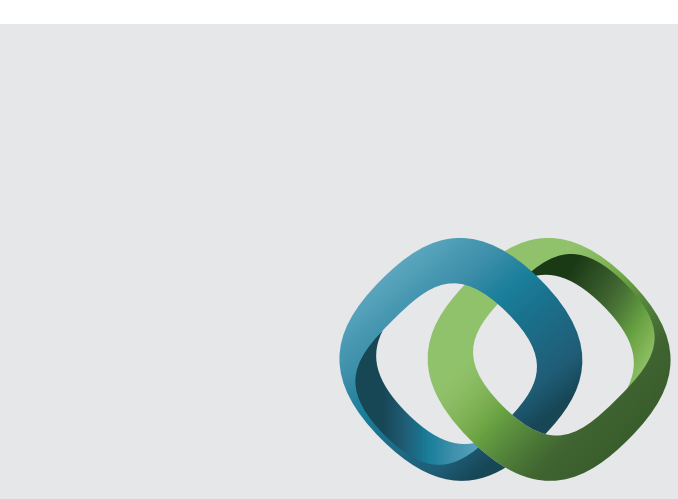

\section{Hindawi}

Submit your manuscripts at

http://www.hindawi.com
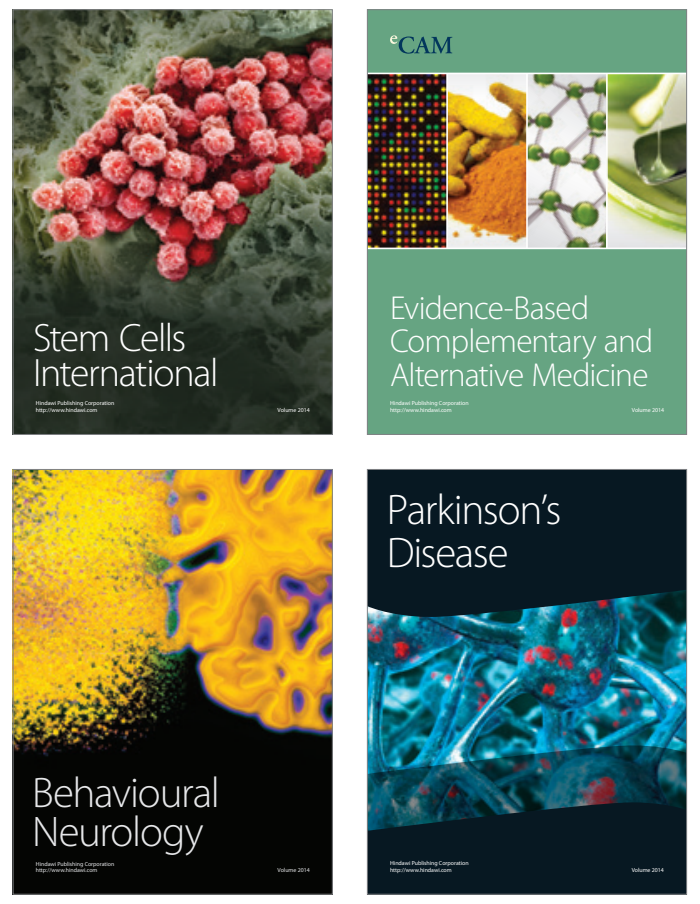
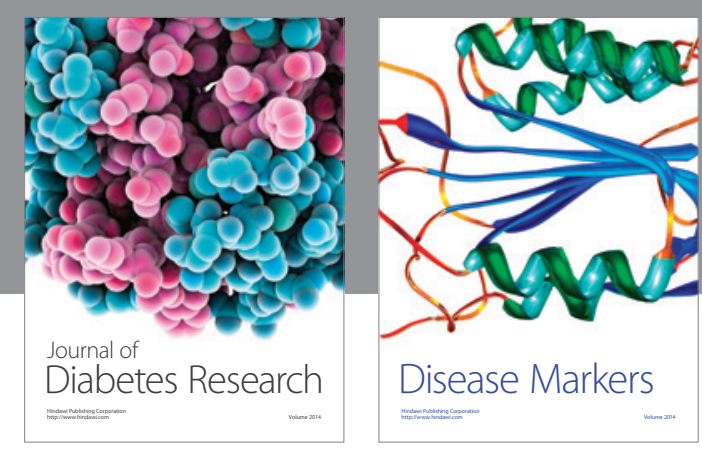

Disease Markers
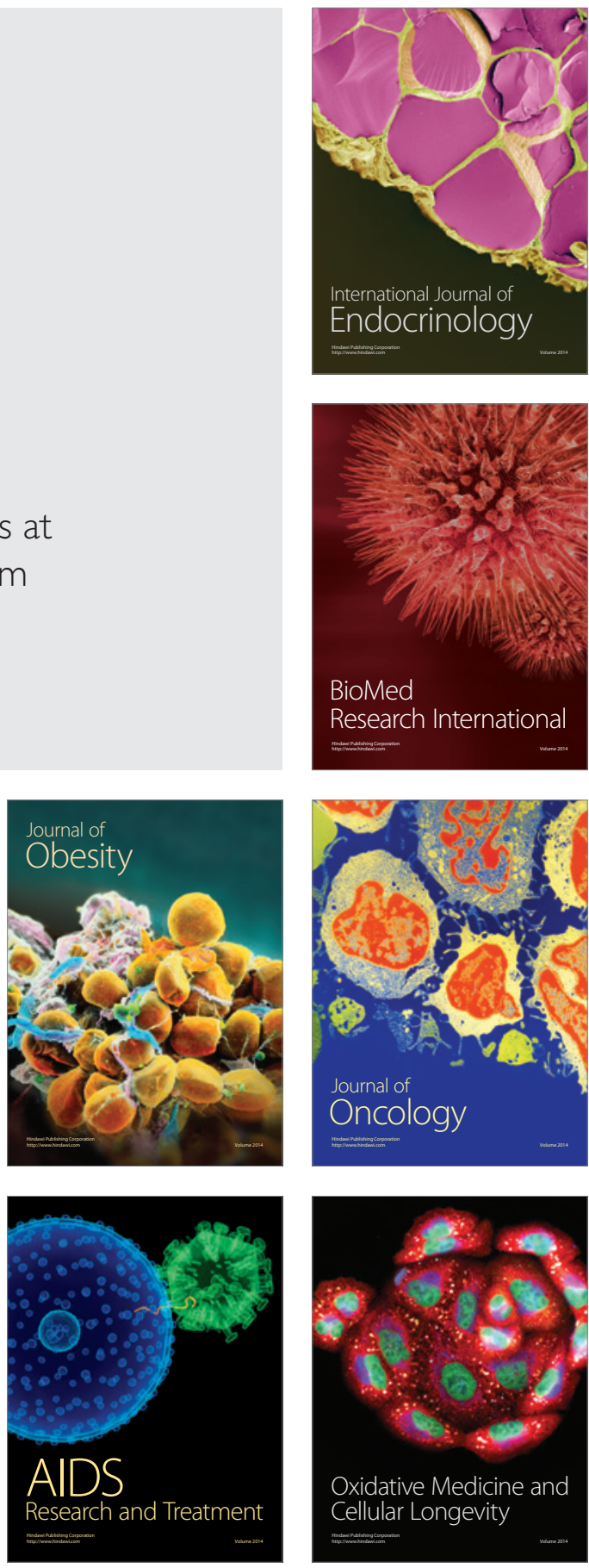